\title{
The nexus: Reconsidering environmental security and adaptive capacity
}

R. de Grenade ${ }^{\mathrm{a}^{*}}$, L. House Peters ${ }^{\mathrm{b}}$, C.A. Scott ${ }^{\mathrm{a}}$, B. Thapa ${ }^{\mathrm{b}}$, M. Mills-Novoa $^{\mathrm{b}}$, A. Gerlak ${ }^{\mathrm{c}}$, and K. Verbist $^{\mathrm{d}}$

${ }^{a}$ University of Arizona, Udall Center for Studies in Public Policy, 803 E. First St., Tucson, AZ 85719 , USA

${ }^{\mathrm{b}}$ School of Geography and Development, ENR2 Building, South 4th floor, P.O. Box 210137 Tucson, AZ 85721-0137, USA

${ }^{c}$ Udall Center for Studies in Public Policy, 803 E. First St., Tucson, AZ 85719, USA

${ }^{\mathrm{d}}$ UNESCO-International Hydrological Programme, Hydrological Systems \& Water Scarcity Section, Enrique Delpiano 2058, Santiago, Chile.

Corresponding author: R. de Grenade

email: rdegrenade@email.arizona.edu

\begin{abstract}
The water-energy-food nexus has emerged as a productive discourse and methodology in academic research, science-policy dialogues, and development agendas. While the nexus provides a robust framework for interdisciplinary study, research remains focused on synergies and tradeoffs in resource "security" and fails to adequately acknowledge the environment as the set of natural processes underpinning the nexus, particularly interactions among water, energy, and food. Resource security as a reductionist discourse does not address the limitations and potential of natural processes and the dynamic nature of human processes, especially adaptation to global changew A review of recent literature highlights the need to redefine the nexus to fundamentally incorporate the environment, and, drawing on social-ecological systems thinking, to integrate considerations of adaptive capacity and resilience within nexus theory and practice. Future directions for this line of inquiry include identifying feasible ways of assessing the nexus in the context of dynamic social and ecological systems, and implications that adaptive actions have across resource-use sectors and the environment. A more holistic nexus framework enhances our options to manage environmental interactions, human activities, and policies to adapt to global-change uncertainties.
\end{abstract}


Keywords: Human-environment nexus, food-energy-water-environment nexus, social-ecological systems, adaptive capacity, environmental security

\section{Introduction}

The "nexus" concept has surged in academic, policy and development agendas as an integrative approach to analyzing and promoting sustainable development, good governance, and social equity [1-4]. The nexus concept explores interactions of multiple sectors across multiple scales, specifically management of food, water, and energy security in local, regional, and transboundary settings, and the tradeoffs and synergies created by competing resource use and policy agendas, requiring cross-sector and cross-scalar coordination and integration of resource management and environmental governance [4-9].

The concepts of environment, land, ecosystems, ecosystem services, and climate change play a structural role in these discussions, however the context of how these concepts are integrated, at what scales, for whom, and to what end varies widely. Furthermore, within nexus scholarship, consideration of social-ecological systems theory, resilience, and adaptive capacity remain largely unexplored $\left[10^{*}, 11\right]$. Increasingly faced with concerns of resource scarcity, competition and conflict over resources, population pressure, and planetary boundaries, achieving resource "security" has taken precedence as an end goal [12-14], often without acknowledging the power relations that benefit from the resource security discourse, or the inherent adaptability of socialecological systems. This has led to critiques of the water-energy-food (WEF) nexus framework as dominated by economic market valuation and lacking explicit attention to social and environmental risks [15*], environmental justice [16], and livelihoods [17**]. The current WEF nexus discourse fails to adequately consider the politics inherent in food, water, and energy. Frameworks and approaches for integrating participatory and reflexive governance processes, stakeholder engagement, and policy experimentation within nexus scholarship are needed [18]. The aim of this review is to demonstrate the need to bring environmental considerations and the potential of adaptive capacity and coupled social-ecological systems thinking into nexus research and practice.

\section{Environment in the nexus}


Early discussions of the nexus included the environment as one of four primary elements: the water-energy-food-environment nexus, or interface [19,20]. In the stage-setting 2011 Bonn Conference, ecosystem services, green economy, and social justice were presented as pillars of the concept, and since this time, ecosystem services continues to surface as a framing concept $[21,22]$ or a key focus of the nexus [23]. The nexus debate has seen its strongest proponents in the water sector: water security is often privileged within the triple-resource nexus [24] and many of the scales chosen and environmental contexts argued are water-centric [25-30]. The definition of water security, unlike the definitions used in other sectors (food and energy) has fairly consistently included the twin concepts of environmental justice and environmental sustainability as key components [31-33].

However, thus far, even the most innovative nexus research, policy, and integrative management approaches - including resource scarcity, governance and public policy, environmental risk and hazards, or general environmental sustainability in the context of economic growth and social wellbeing [34**-37] — have assessed environmental sustainability from a human-centric perspective. The danger here is that research and policy decisions related to the natural world are driven by a concern for the survival of the human species, without adequate consideration for the magnitude, potential, and complexity of earth systems. This evident bias in the literature clearly indicates the need to reinforce the local and planetary scale of the 'environment,' and extend the definition to include the inherent, or existence value of planetary systems, in addition to their value for humanity.

\section{Environmental security and the nexus}

Similarly, the environmental security literature has failed to adequately acknowledge complex systems dynamics, including adaptive capacity and adaptive action. The concept of "security" assesses what is to be protected and against which dangers [38]. Environmental or ecological security was first formally expressed in relation to human security by Ullman [39] and subsequently expanded on by Mische [40], Myers [41], Litfin [42], and Dalby [43]. Environmental/ecological security research and theory recognize direct and indirect threats to human survival from natural hazards and disasters, environmental degradation, the inherent and human-induced limits to natural resources, and environmental (global) change [44,45]. The 
emergent concepts of human-environmental security [46*], environmental livelihood security [17**], and Future Earth's 2025 vision [http://www.futureearth.org/media/future-earth-2025vision/] explore social-ecological resilience and transformative, sustainable solutions by optimizing WEF linkages and striving to achieve a balance between human demand on the environment and environmental impacts on humans.

Resource security presupposes an obtainable end goal in sustained resource availability. The concept of security, aside from debates of power, knowledge and the influence of the market [47], assumes that natural and social systems may attain equilibria. As adaptive capacity scholarship suggests, humans and the cultures and societies they create are constantly changing, adapting to a changing environment, and developing new relationships with the natural world, with resources, and with each other [48-51]. Similarly, human-induced climate change as a positive feedback cycle induces physical changes to the environment that stimulate adaptation, extinction, and evolution in natural systems. These various internal and external drivers preclude a static concept of "security"; instead, a more useful way of formulating this complexity is to think of adaptive capacity and resilience within the context of constantly changing earth systems.

\section{Re-conceptualizing the nexus}

To address these limitations, this review exposes a need to liberate nexus thinking from a restrictive focus on resource security, and environmental hazards and concerns. The strength of nexus research lies in its reliance on an integrative approach to scholarship and policy development. However, nexus research's narrow focus on a few selected resources limits its potential to adequately engage the multiple systems needed to sustain human wellbeing in its complex interdependence with the environment. Nexus research should firmly include the environment as a fundamental conceptual framing: the environment provides the resources needed to support security and human well being; the environment is the source of multiple drivers and stressors that stimulate the need for adaptive capacity and action; and the environment is a series of complex, dynamic, interlinked systems that are affected by, but exist independent of, human actions.

Second, the review of the literature suggests nexus research would benefit from a tighter engagement with the social-ecological systems (SES) framework, which presumes an underlying 
integration of human and natural systems [52-54]. Particularly when SES perspectives inform nexus thinking, the dynamics of ecological processes, societal adaptation, and their mutual conditioning are seen to give rise to emergent properties of the coupled SES, while simultaneously offering opportunities for adaptive action that confer or strengthen resilience [55]. That is, it is primarily through overt consideration of interlinked social and ecological dynamics that human extraction and use of nexus resources may be able to occur within stability limits (Figure 1). Alternately, resource use without social and institutional "learning," (i.e., without explicit efforts to assess and measure social impacts of the nexus and ecological conditions that arise), may be maladaptive and give rise to further loss of ecological function and erode resilience [56]. Critiques of SES thinking and related concepts of resilience and adaptive capacity focus on these concepts as being too generalized without reference to unique systems or specific contexts [57]. This raises justifiable concerns over the deeply political dimensions of nexus research particularly in terms of structural power inequities related to class, race, and gender. Further, the political ecology of nexus approaches cannot be neglected, as they highlight the historical, cultural and socio-political dimensions that underpin a given resource nexus $\left[58^{*}, 59\right]$.

A reformulation of the nexus framework moves beyond the narrowly conceived and humancentric resource security nexus to a conceptualization that explicitly acknowledges the environment as a provider of resources, a source of drivers, stressors, and feedbacks, and a highly complex and dynamic set of systems with inherent value beyond human use. While the typical nexus framework privileges an emphasis on human system-centered approaches to understanding resource security and scarcity (see Figure 1a) with little attention to systems resilience, systems change, or adaptive capacity, a re-conceptualized nexus (see Figure 1b) recognizes the limits imposed by earth systems and the drivers and feedbacks between earth systems and coupled human and natural systems.

Figure 1a. Conventional resource security nexus conceptualization

Figure 1b. Re-conceptualization toward a more holistic nexus

A re-conceptualized nexus framework illustrates the integration of critical earth systems functions adapted from the planetary boundary framework $[60,61 * *]$, and the addition of 
adaptive capacity as a complementary component to the resource security nexus. Planetary boundary scholarship proposes that earth systems contain their own inherent thresholds, boundaries, and dynamics, which present complex drivers, synergies, conflicts, and limits to existing models of environmental governance $[62,63]$. As a quantitative metric, the planetary boundary framework identifies nine variables critical to the operation of earth systems for the continued habitability of earth [60], with a tenth variable, terrestrial net primary production, recently quantified [64].

The assessment of adaptive capacity, derived from SES perspectives on vulnerability and resilience [65-67*], is an additional class of metrics applied to environmental systems to gauge the ability of systems to cope with and recover from stress. Adaptive capacity is theorized as both affecting a system's vulnerability through the modulation of exposure and sensitivity, and as critical to managing SES resilience by regulating the maintenance of system functioning. The adaptive capacity wheel presents one assessment metric, operationalized through the identification and quantification of eight dimensions of adaptive capacity $[68,69]$.

An important next step will be to identify feasible ways of assessing the nexus and implications that adaptive actions have on coupled human-natural systems. Specific future challenges exist in the application of metrics to the nexus, specifically in identifying standardized metrics that apply to all spheres of the nexus as proposed in the re-conceptualized diagram, across multiple scales. One approach is to think in terms of availability, quantity, and quality of resources; diversity - to include biodiversity as well as a diversity of actors involved in decision-making, modes of governance, and sources of resources; and systems functioning - to identify and integrate metrics of social and ecological metabolism [34**]. Another useful approach for developing nexus metrics comes from the planetary boundaries scholarship, which has employed an integrated mixed methods approach, including measures of diversity, availability, quantity, and quality, to develop metrics that define and assess multi-scalar thresholds deemed essential for the functioning of earth systems [60,61**]. We are not advocating for the application of modeling to these systems, but rather a means of identifying baseline conditions and comparing progress in the context of social and ecological changes.

\section{Conclusions}


Our review of the literature highlights a need to re-conceptualize nexus scholarship and practice to fundamentally include the environment or earth systems as a framing concept, and engage social-ecological systems and adaptive capacity research. This will not only strengthen the value of an integrative nexus concept, but will provide fertile ground for reimagining dynamic, resilient human-environmental interactions and adaptation opportunities within the context of complex earth systems. Such an approach aims to move beyond the reductionist discourse that presently fails to address the limitations and potential of natural processes and the dynamic nature of human processes, especially adaptation to global change. This approach offers new conceptual and methodological measures to assess environmental security, resilience, and adaptive capacity in the context of dynamic systems. Ideally, the nexus should consider natural systems and flows as a fundamental underpinning of resource availability, while engaging the complex relations of human and natural systems, and acknowledging planetary boundaries. Future directions for research and study are needed to better integrate considerations of adaptive capacity and resilience within nexus theory and practice. One important line of inquiry includes identifying feasible ways of assessing the nexus in the context of dynamic social and ecological systems, and implications that adaptive actions have across resource-use sectors. Ultimately, such pathways may likely reveal how a more holistic nexus framework enhances our options to manage environmental interactions, human activities, and policies to adapt to global-change uncertainties.

\section{Acknowledgements}

We wish to express our gratitude to Margaret Wilder and Gregg Garfin for coordinating the workshop "Metrics and Measurement of Adaptation and Water Security: Advances in Water Research in the Arid Americas," convened by the Udall Center for Studies in Public Policy at the University of Arizona, at which we initiated these discussions. Special thanks are due to Robert Merideth for editing input. We acknowledge partial support for this review from the International Water Security Network, funded by Lloyd's Register Foundation (LRF), a charitable foundation in the United Kingdom helping to protect life and property by supporting engineering-related education, public engagement, and the application of research; from the Inter-American Institute for Global Change Research (IAI), for Project SGP-CRA005, which is supported by U.S. 
National Science Foundation (NSF) grant GEO-1138881, and for Research Project CRN3056, which is supported by NSF grant GEO-1128040; and from NSF Grant DEB-1010495.

\section{References}

[1] Hoff H: Understanding the Nexus, Background Paper for the Bonn 2011 Conference: The Water, Energy and Food Security Nexus. Stockholm Environment Institute, Stockholm; 2011.

[2] World Economic Forum: Water Security: Water-Food-Energy-Climate Nexus. The World Economic Forum Water Initiative, Island Press, 2011.

[3] Leck H, Conway D, Bradshaw M, Rees J: Tracing the Water-Energy-Food Nexus: Description, Theory and Practice. Geography Compass 2015, 9(8): 445-60.

[4] Siddiqi A, Kajenthira A, Anadón LD. Bridging decision networks for integrated water and energy planning. Energy Strategy Reviews. 2013, 2(1): 46-58.

[5] Howells B, Rogner RH: Water-energy nexus: Assessing integrated systems. Nature Climate Change 2014, 4: 246-247.

[6] Benson D, Gain AK, Rouillard, JJ: Water governance in a comparative perspective: From IWRM to a 'nexus' approach? Water Alternatives 2015, 8(1): 756-773.

[7] de Strasser L, Lipponen A, Howells M, Stec S, Bréthaut C: A methodology to assess the water energy food ecosystems nexus in transboundary river basins. Water 2015, 7, DOI:10.3390/w70x000x

[8] Karlberg L, Hoff H, Amsalu T, Andersson K, Binnington T, Flores-López F, de Bruin A, Gebrehiwot SG, Gedif B, zur Heide F, Johnson O, Osbeck M, Young C: Tackling complexity: Understanding the food-energy-environment nexus in Ethiopia's Lake Tana Sub-basin. Water Alternatives 2015, 8(1): 710-734.

[9] Mirzabaev A, Guta D, Goedecke J, Gaur V, Borner J, Virchow D, Denich M, von Braun J: Bioenergy, food security and poverty reduction: Trade-offs and synergies along the water- 
energy-food security nexus. Water International 2015: 1-19.

[10]* Scott CA, Kurian M, Wescoat JL Jr.: The Water-energy-food nexus: Adaptive capacity to complex global challenges. In M. Kurian and R. Ardakanian (eds.). Governing the Nexus: Water, Soil and Waste Resources Considering Global Change 2015, Springer, Berlin, pp. 15-38.

This chapter contributes to the larger volume, Governing the Nexus: Water, Soil and Waste Resources Considering Global Change (Springer, 2015) by introducing institutional and humanenvironmental security dimensions of the water, food, and energy nexus. It traces the history and background of the nexus to South Asia, and suggests that its future applicability in conceptual and operational terms is of particular salience in this region currently experiencing insecurity of water, energy, and food.

[11] Hussey K, Pittock J: The Energy-Water Nexus: Managing the Links between Energy and Water for a Sustainable Future. Ecology and Society 2012,17(1): 31. http://dx.doi.org/10.5751/ES-04641-170131

[12] Allouche J, Middleton C, Gyawali D: Nexus nirvana or nexus nullity? A dynamic approach to security and sustainability in the water-energy-food nexus. STEPS Working Paper 63, Brighton, UK: STEPS Centre; 2014.

[13] Wong KV: Energy-water-food nexus and recommendations for security. Journal of Energy Resources and Technology 2015, 137: 1-4.

[14] Gerlak AK, Mukhtarov F. Many faces of security: Discursive framing in cross-border natural resource governance in the Mekong River Commission. Globalization 2016, (forthcoming).

[15]*Allan T, Keulertz M, Woertz E: The water-food-energy nexus: An introduction to nexus concepts and some conceptual and operational problems. International Journal of Water Resources Development 2015, 31(3): 301-311.

The authors argue that operationalizing the nexus has been problematic, in part due to different systems of valuation, especially under conditions of scarcity, for each resource (water, energy, food) accounted for within the nexus. Within the grand WEF nexus, there are sub-nexi that are 
asymmetrically theorized, leading to poor understanding of how the sub-nexi interact within the grand nexus, especially in terms of economic valuation of the resources individually and in relation to each other.

[16] Middleton C, Allouche J, Gyawali D, Allen S: The rise and implications of the waterenergy-food nexus in Southeast Asia through an environmental justice lens. Water Alternatives 2015, 8(1): 627-654.

[17] **Biggs EM, Bruce E, Boruff B, Duncan JMA, Horsley J, Pauli N, McNeill K, Neef A, Van Ogtrop F, Curnow J, Haworth B, Duce S, Imanari Y: Sustainable development and the waterenergy nexus: A perspective on livelihoods. Environmental Science \& Policy 2015, 54: 389397.

The authors recognize the lack of attention to sustainable livelihoods within the nexus approach, which they argue has negative implications for effectively utilizing the nexus framework to achieve sustainable development, where livelihoods are a key concern. The article advances an integrated nexus-livelihoods framework, termed "Environmental Livelihood Security" that reformulates the environmental security nexus to acknowledge the central role of sustainable livelihoods in the goal of achieving a balance between human demand on the environment and environmental impacts on humans.

[18] Halbe J, Pahl-Wostl C, Lange MA, Velonis C: Governance of transitions towards sustainable development - the water-energy-food nexus in Cyprus. Water International 2015, DOI: 10.1080/02508060.2015.1070328.

[19] Hellegers P, Zilberman D, Steduto P, McCornick P: Interactions between water, energy, food and environment: evolving perspectives and policy issues. Water Policy 2008, 10(1): 110 .

[20] McCornick PG, Awulachew SB, Abebe M: Water-food-energy-environment synergies and tradeoffs: major issues and case studies. Water Policy 2008, 10(1): 23-36.

[21] ICIMOD (International Centre for Integrated Mountain Development): Contribution of Himalayan ecosystems to water, energy, and food security in South Asia: A nexus approach. 
Kathmandu, Nepal: International Centre for Integrated Mountain Development; 2012.

[22] Bizikova L, Roy D, Swanson D, Venema HD, McCandless M: The Water-Energy-Food Security Nexus: Towards a Practical Planning and Decision-Support Framework for Landscape Investment and Risk Management. IISD Report, International Institute for Sustainable Development (IISD), 2013. http://www.iisd.org/pdf/2013/wef_nexus_2013.pdf.

[23] *Rasul G: Food, water, and energy security in South Asia: A nexus perspective from the Hindu Kush Himalayan region. Environmental Science and Policy 2014, 39: 35-48.

The author explores regional food, water, and energy nexus dynamics in southwest Asia, and places a key emphasis on the role of Hindu Kush Himalayan ecosystem services in sustaining downstream ecosystems and communities.

[24] Beck MB, Walker RV. On water security, sustainability, and the water-food-energyclimate nexus. Frontiers of Environmental Science \& Engineering 2013, 7(5): 626-639.

[25] Lawford R, Bogardi J, Marx S, Jain S, Pahl Wostl C, Knüppe K, Ringler C, Lansigan F, Meza F: Basin perspectives on the water-energy-food security nexus. Current Opinion in Environmental Sustainability 2013, 5: 607-616.

[26] Kibaroglu A, Gürsoy SI: Water-energy-food nexus in a transboundary context: the Euphrates-Tigris river basin as a case study. Water International 2015, DOI: 10.1080/02508060.2015.1078577.

[27] Mayor B, López-Gunn E, Villarroya FI, Montero E: Application of a water-energy-food nexus framework for the Duero river basin in Spain. Water International 2015, DOI:10.1080/02508060.2015.1071512.

[28] Meza FJ, Vicuna S, Gironás J, Poblete D, Suárez F, Oertel M: Water-food-energy nexus in Chile: the challenges due to global change in different regional contexts. Water International 2015, DOI: 10.1080/02508060.2015.1087797.

[29] Muller M: The 'nexus' as a step back towards a more coherent water resource management paradigm. Water Alternatives 2015, 8(1): 675-694. 
[30] Vanham D: Does the water footprint concept provide relevant information to address the water food-energy-ecosystem nexus? Ecosystem Services 2015, DOI:10.1016/j.ecoser.2015.08.003i.

[31] Grey D, Sadoff CW: Sink or swim? Water security for growth and development. Water Policy 2007, 9(6): 5450-571.

[32] Scott CA, Meza FJ, Varady RG, Tiessen H, McEvoy J, Garfin GM, Wilder M, Farfán LM, Pineda Pablos N, Montaña E: Water security and adaptive management in the arid Americas. Annals of the Association of American Geographers 2013, 103(2): 280-289.

[33] UN Water: UN-Water Analytical Brief on Water Security and the Global Water Agenda, 2013. United Nations University, 2013.

[34] **Giampietro M, Aspinall RJ, Ramos-Martin J, Bukkens SGF: Resource Accounting for Sustainability Assessment - The Nexus Between Energy, Food, Water and Land Use. Routledge, Explorations in Sustainability and Governance, 2014.

The authors present a multi-scale methodology of integrated resource and sustainability assessment, specifically exploring societal and ecosystem metabolism. The authors present three detailed case studies: the islands of Mauritius, the Indian state of Punjab, and the energy economy of South Africa to analyze resource flows in relation to natural systems.

[35] Bizikova L, Roy D, Swanson D, Venema HD, McCandless M: Water-Energy- Food Nexus and Agricultural Investment: A Sustainable Development Guidebook. International Institute for Sustainable Development (IISD), 2014. http://www.iisd.org/pdf/2014/WEF_guidebook.pdf.

[36] UNECE (United National Economic Commission for Europe): Reconciling resource uses in transboundary basins: Assessment of the water-food-energy-ecosystems nexus. Geneva, 2015.

[37] Gain AK, Giupponi C, Benson D: The water-energy-food (WEF) security nexus: the policy perspective of Bangladesh. Water International 2015: 1-16.

[38] Dimitrov RS: Water, conflict, and security: A conceptual minefield. Society and Natural Resources: An International Journal 2002, 15(8): 677-691, DOI: 10.1080/08941920290069281. 
[39] Ullman RH: Redefining security. International Security 1983, 8(1): 129-153.

[40] Mische PM: Ecological security and the need to reconceptualize sovereignty. Alternatives XIV 1989, 14(4): 389-427.

[41] Myers N: Ultimate Security: The Environmental Basis of Political Stability. W. W. Norton, New York, 1993.

[42] Litfin KT: Constructing environmental security and ecological interdependence. Global Governance 1999, 359-377.

[43] Dalby S: Security and Environmental Change. Polity, Cambridge; 2009.

[44] Westing AH: From Environmental to Comprehensive Security. Springer, London, 2013.

[45] Scott CA, Thapa B: Environmental security. Oxford University Press, 2015, DOI:10.1093/obo/9780199363445-0012.

[46] *Endo A, Burnett K, Orencio PM, Kumazawa T, Wada CA, Ishii A, Tsurita I, Taniguchi M: Methods of the Water-Energy-Food Nexus. Water 2015, 7: 5806-5830;

DOI:10.3390/w7105806.

The authors employ an innovative combination of quantitative and qualitative methods to analyze the water-energy-food nexus in case studies from two countries. The methods involve fine-scale participatory processes, secondary source indices and analyses, and systems modeling to unify related variables, visualize nexus interactions, and simulate nexus systems.

[47] Leese M, Meisch S: Securitising sustainability? Questioning the 'water, energy and food-security nexus'. Water Alternatives 2015, 8(1).

[48] Smit B, Wandel J: Adaptation, adaptive capacity, and vulnerability. Global Environmental Change 2006, 16: 282-292.

[49] Pahl-Wostl C: A conceptual framework for analyzing adaptive capacity and multi-level learning processes in resource governance regimes. Global Environmental Change 2009, 19: 354-365. 
[50] Moser SC, Ekstrom JA: A framework to diagnose barriers to climate change adaptation. Proceedings of the National Academy of Sciences (PNAS) 2010, 107(51): 2202622031.

[51] Filho WL (Ed): Handbook of Climate Change Adaptation. Springer, New York; 2015.

[52] Walker BH, Anderies JM, Kinzig AP, Ryan P. Exploring resilience in social-ecological systems through comparative studies and theory development: introduction to the special issue. Ecology and Society 2006, 11(1):12.

[53] Gunderson LH, Craig RA, Holling CS (Eds.). Foundations of Ecological Resilience. Island Press, Washington, D.C.; 2010.

[54] Walker B, Salt D: Resilience Practice: Building Capacity to Absorb Disturbance and Maintain Function. Island Press, Washington D.C.; 2012.

[55] Chaffin BC, Gosnell H, Cosens BA: A decade of adaptive governance scholarship: Synthesis and future directions. Ecology and Society 2015, 19(3): 56.

[56] Barnett J, O’Neill S: Maladaptation. Global Environmental Change 2011, 20: 211-213.

[57] Cote M, Nightingale J: Resilience thinking meets social theory: Situating social change in social-ecological systems (SES) research. Progress in Human Geography 2012, 36: 475489.

[58] *Allouche, J, Middleton C, Gyawali D: Technical veil, hidden politics: Interrogating the power linkages behind the nexus. Water Alternatives 2015 8(1): 610-626.

The authors deconstruct the nexus to demonstrate the problematic framing of the nexus in terms of global resource scarcity and implications for economic growth, which they argue lead to resource policy and governance solutions dominated by technology and the market, thus ignoring social and environmental justice and politics, more generally.

[59] Foran T: Node and regime: Interdisciplinary analysis of water-energy-food nexus in the Mekong region. Water Alternatives 2015, 8(1): 655-674. 
[60] Rockstrom J, Steffen W, Noone K, Persson A, Chapin III FS, Lambin EF, Lenton TM, Scheffer M, Folke C, Schellnhuber HJ, Nykvist B, de Wit CA, Hughes T, van der Leeuw S, Rodhe H, Sorlin S, Snyder PK, Costanza R, Svedin U, Falkenmark M, Karlberg L, Corell RW, Fabry VJ, Hansen J, Walker B, Liverman D, Richardson K, Crutzen P, Foley JA: A safe operating space for humanity. Nature 2009, 461(24): 472-475.

[61] **Steffen W, Richardson K, Rockstrom J, Cornell SE, Fetzer I, Bennett EM, Biggs R, Carpenter SR, de Vries W, de Wit CA, Folke C, Gerten D, Heinke J, Mace GM, Persson LM, Ramanathan V, Reyers B, Sorlin S. Planetary boundaries: Guiding human development on a changing planet. Science 2015, 347(6223): 1-10.

Updating the original planetary boundaries framework for measuring risk to earth system functioning in the Anthropocene, the authors describe newly developed regional-level boundaries for biosphere integrity, biogeochemical flows, land-system change, and freshwater use, and recognize climate change and biosphere integrity as core boundaries due to their critical role in regulating earth system functions.

[62] Biermann F: Planetary boundaries and earth system governance: Exploring the links. Ecological Economics 2012, 81: 4-9.

[63] Galaz V, Biermann F, Crona B, Loorbach D, Folke C, Olsson P, Nilsson M, Allouche J, Persson A, Reischl G. 'Planetary boundaries' - exploring the challenges for global environmental governance. Current Opinion in Environmental Sustainability 2012, 4: 80-87.

[64] Running SW: A measurable planetary boundary for the biosphere. Science 2012, 337: 1458-1459.

[65] Engle NL: Adaptive capacity and its assessment. Global Environmental Change 2011, 21: 647-656.

[66] Hill M, Engle NL: Adaptive capacity: Tensions across scales. Environmental Policy and Governance 2013, 23: 177-192.

[67]*Lockwood M, Raymond CM, Oczkowski E, Morrison M: Measuring the dimensions of adaptive capacity: A psychometric approach. Ecology and Society 2015, 20 (1): 37. 
Advancing metrics to assess adaptive capacity, the authors introduce a psychometric approach to identify and measure dimensions of adaptive capacity. The novel psychometric approach facilitates the integration of primary data into adaptive capacity metrics and identifies individual's orientation to change as a key explanatory variable for adaptive capacity, which previously had not been recognized.

[68] Gupta J, Termeer C, Klostermann J, Meijerink S, van den Brink M, Jong P, Nooteboom S, Bergsma E: The Adaptive Capacity Wheel: A method to assess the inherent characteristics of institutions to enable the adaptive capacity of society. Environmental Science and Policy 2010, 13: 459-471.

[69] Grothmann T, Grecksch K, Winges M, and Siebenhuner B: Assessing institutional capacities to adapt to climate change: Integrating psychological dimensions in the Adaptive Capacity Wheel. Natural Hazards and Earth System Sciences 2013, 13: 3369-3384. 


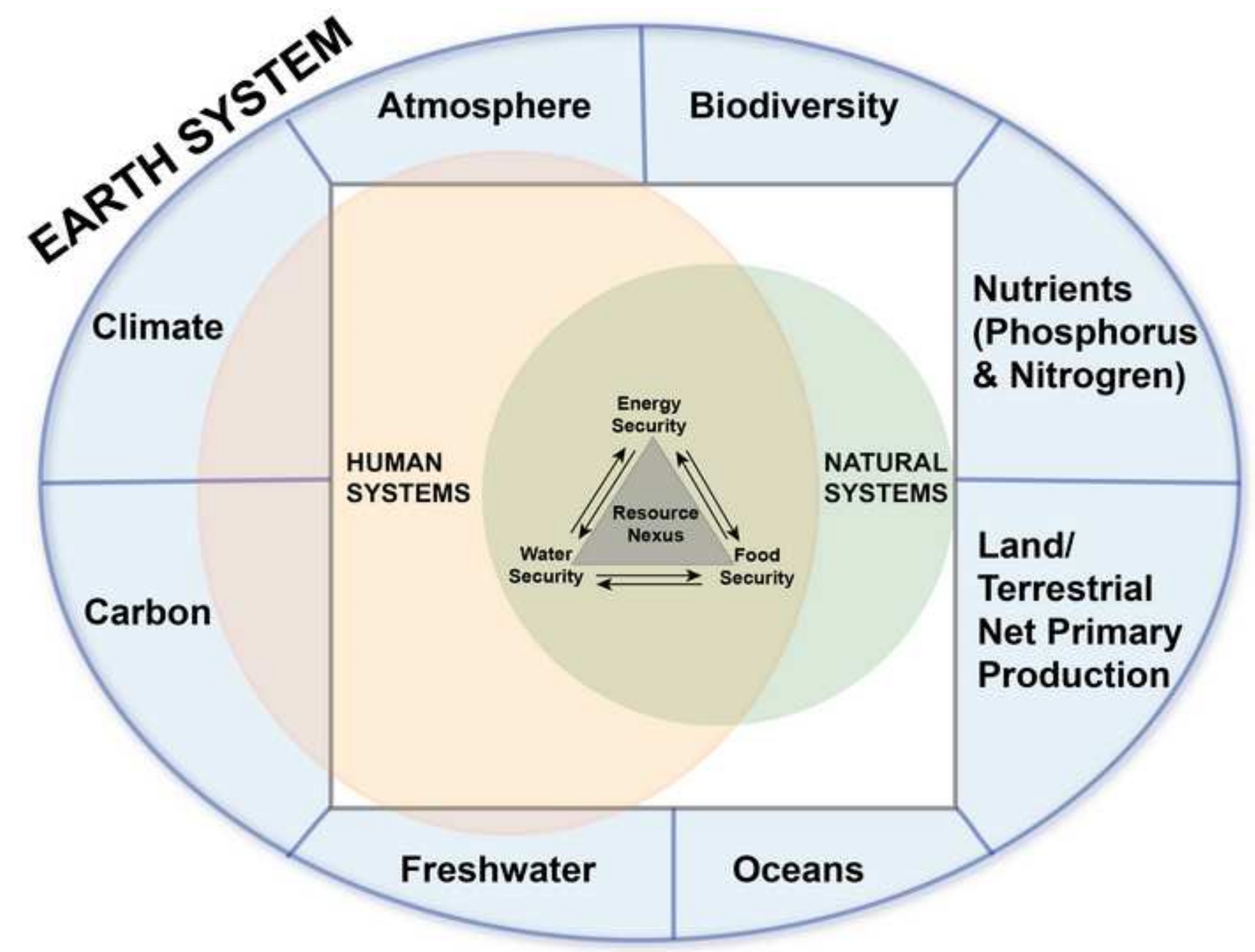




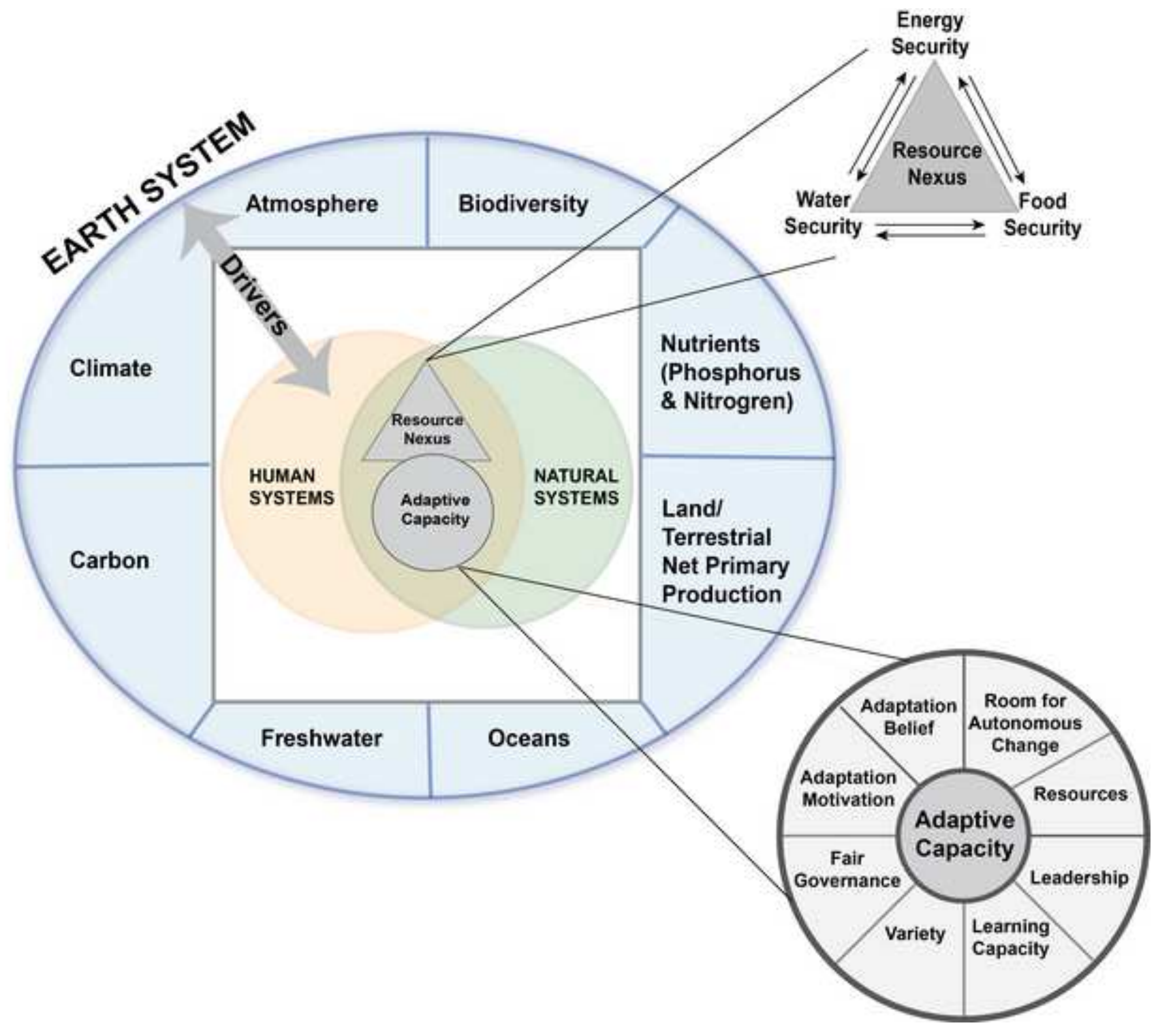

